\title{
COMPARATIVE STUDIES OF PHYTOCHEMICAL AND ANTIOXIDANT ACTIVITY OF IN VIVO PLANT AND IN VITRO CALLUS EXTRACT OF CARDIOSPERMUM HALICACABUM L.
}

\author{
THANIARASU R*, LOGESHWARI M
}

Department of Botany, Science Campus, Alagappa University, Karaikudi, Tamil Nadu, India. Email: chellathani@gmail.com

Received: 26 May 2021, Revised and Accepted: 30 June 2021

ABSTRACT

Objective: The present investigation focuses on the use of Cardiospermum halicacabum L. in their phytochemical and biological activities.

Methods: In this study, in vivo stem and in vitro callus ethanolic extracts of $C$. halicacabum were tested for their phytochemical attributes by qualitative method, Fourier transform infrared (FTIR), antioxidant, antibacterial, and bioactive compound properties. The bactericidal activity of the in vivo stem and in vitro callus extract has been evaluated in both $\mathrm{Gram}^{+\mathrm{ve}}$ and $\mathrm{Gram}^{\text {-ve }}$ microorganisms using the disk diffusion method.

Results: The highest frequency (78\%) of well developed, dark green organogenic callus was induced from stem explant on Murashige and Skoog (MS) medium supplemented with $0.7 \mathrm{mg} / \mathrm{l}$ 2,4-Dichlorophenoxyacetic acid (2, 4-D) and $0.5 \mathrm{mg} / \mathrm{l}$ benzyl adenine (BA). The results of FTIR spectra confirmed the presence of functional groups in wild stem and in vitro callus extract of $C$. halicacabum with various peaks. The total phenolic content in ethanolic extract of in vivo plant and in vitro callus was $80.46 \mathrm{mg}$ gallic acid equivalent (GAE)/g dry weight and 76.4 mg GAE/g dry weight, respectively. The highest percentage of tannins was measured at 78.03 in wild stem ethanol extracts followed by 75.22 in callus extract. The antioxidant activity of 2,2-diphenyl-2picrylhydrazyl (DPPH) ethanol extract was found to be $206.54 \mu \mathrm{g} / \mathrm{ml}$. IC50 values of the stem extracts of $C$. halicacabum are $306 \mu \mathrm{g} / \mathrm{ml}$ and $286 \mu \mathrm{g} / \mathrm{ml}$ in callus extract, respectively. Antibacterial activity of the ethanol extract was higher for Staphylococcus aureus (S. aureus) with a 17 mm zone of inhibition.

Conclusion: The present investigation recommended that the callus ethanolic extract function as a good source of biologically active compounds and natural antioxidants.

Keywords: Cardiospermum halicacabum, Antibacterial activity, Phytochemicals, Antioxidant activity.

(C) 2021 The Authors. Published by Innovare Academic Sciences Pvt Ltd. This is an open access article under the CC BY license (http://creativecommons.org/ licenses/by/4.0/) DOI: http://dx.doi.org/10.22159/ajpcr.2021v14i8.42197. Journal homepage: https://innovareacademics.in/journals/index.php/ajpcr

\section{INTRODUCTION}

Medicinal plants are natural properties of bioactive phytochemical constituents which, for the physiological activities delivered on the human organism, can be employed against various ailments. Therefore, it is essential for medicinal plants to be evaluated for their phytochemistry so as to determine the ability of these indigenous sources of medicinal products [1]. Cardiospermum halicacabum L. (Balloon vine) belonging to the family Sapindaceae. C. halicacabum belonging a medicinal plant rich in $\beta$-sitosterol, D-glucoside, Saponin, and Quebrachitol. C. halicacabum is also used to treat diarrhea, dysentery, nephritis, oliguria hemorrhoids, asthma, earaches, muscular pains, nervous disorders, and rheumatism [2]. The entire plant has been used for some centuries in the treatment of atrophic arthritis, stiffness of the limbs, and snakebite; the decoction from its roots is used as a diuretic, emetic, and for laxative; the decoction of its leaves and stems is used in cases of diarrhea, dysentery, and headaches; and an ointment of them as a cure for swelling [3]. The ethanolic extract emphasized the existence of various compounds comprising phenolic acids (P-coumaric acid, 4-hydroxybenzoic acid, hydroquinone, protocatechuic acid, and gallic acid); flavonoids (apigenin, kaempferol, luteolin, and quercetin); tannins; and sterols including, campestrini, stigmasterin, and $\beta$-sitosterina. All compounds of $C$. halicacabum have been isolated and evaluated for antioxidant and anti-inflammatory activity [4]. Even though there are several reported publications on $C$. halicacabum phytochemistry in the literature, to date there is no available published report on the comparative phytochemical study of wild (stem) and in vitro callus extract. This prompts us to execute the present work to study the phytochemistry of $C$. halicacabum. The novelty of the present investigation is the detection of the main functional groups such as alcohols, phenols and alkanes in the stem derived callus extract, which could further be used for pharmacological study on this plant

\section{METHODS}

\section{Plant material}

The $C$. halicacabum plant was collected from the spring season in the local area of Karaikudi, Tamil Nadu. Then, the stem was separated and washed under running tap water. The plant material was authenticated at the Department of Botany, Alagappa University, Science Campus, Karaikudi, Tamil Nadu, India. The thoroughly washed stem was allowed for shade drying at room temperature in the laboratory. The dried leaves were ground to a fine powder using a blender.

\section{Surface sterilization}

For callus induction experiment, the stem explants were sterilized with $70 \%$ ethanol for $30 \mathrm{~s}$ followed by $0.1 \%$ bavistin treatment for $5 \mathrm{~min}$ and finally $0.1 \%$ mercuric chloride treatment for $2 \mathrm{~min}$.

\section{Culture conditions}

For callus induction experiment Murashige and Skoog (MS) [5] basal medium supplemented with $30 \mathrm{~g} / \mathrm{l}$ sucrose (HiMedia, India) and gelled with $0.8 \%(\mathrm{w} / \mathrm{v})$ agar (HiMedia, India), and the $\mathrm{pH}$ of the medium was adjusted to $5.7 \pm 0.2$ using $0.1 \mathrm{~N} \mathrm{NaOH}$ or $0.1 \mathrm{~N} \mathrm{HCl}$ after addition of the plant hormones. The medium was autoclaved at $121^{\circ} \mathrm{C}$ and 15 psi pressure for $20 \mathrm{~min}$. All the cultures were maintained in the culture room at $25 \pm 2^{\circ} \mathrm{C}$, under $16 / 8 \mathrm{~h}$ light regime provided by cool white fluorescent light ( $60 \mu_{\mathrm{mol}^{-2}} \mathrm{~s}^{-1}$ light intensity) and with 55-60\% relative humidity.

\section{Callus induction}

After sterilization treatment, the sterilized stem explants were cultured on MS medium supplemented with auxins ( $\alpha$-Naphthalene acetic acid [NAA], Indole-3 acetic acid [IAA] and 2,4-Dichlorophenoxyacetic acid (2, 4-D) $0.5 \mathrm{mg} / \mathrm{l}$ to $2.0 \mathrm{mg} / \mathrm{l}$ ) (HiMedia, India) and cytokinin 6-benzyl 
adenine (BA) $(0.5 \mathrm{mg} / \mathrm{l})$ for callus induction. Callus percentage was recorded after 4 weeks of culture.

\section{Preparation of extracts}

The in vivo grown plant was collected and shade dried for 2-3 weeks. The dried plant materials were then ground into a coarse powder in a mechanical blender and kept in an airtight container. The coarsely powdered sample was weighed $(50 \mathrm{~g})$ and the extract was prepared and was kept on a rotator shaker with $100 \mathrm{ml}$ of ethanol, acetone, petroleum ether, and water solvents each alone for 2 days. The stem extracts were filtered through Whatman No.1 filter paper and collected in a $1 \mathrm{l}$ beaker and they were covered with aluminum foil to avert evaporation. The stem extract of $C$. halicacabum was obtained by using three types of solvents (Petroleum ether, Ethanol, and Aqueous) and stored in an airtight container at $4^{\circ} \mathrm{C}$. Further, the dried residue was preserved in an airtight container or glassware for further analysis. The in vitro grown callus was dried at room temperature for 3 days. The dried callus was macerated using a mortar and pestle. Ten grams of coarsely macerated callus were subjected separately for the extraction using $100 \mathrm{ml}$ distilled water and solvent such as petroleum ether, chloroform, and ethanol.

\section{Preliminary phytochemical studies}

The ethanol extract was evaluated for the following phytochemical components such as reducing sugars, terpenoids, alkaloids, tannins, steroids, flavonoids, saponins, phenolic compounds, amino acids, and anthraquinones.

\section{Test for alkaloids}

Mayer's test

Two milliliters plant sample extract, two drops of Mayer's reagent are included in a test tube. The form of white creamy precipitate specified the existence of alkaloids [6].

\section{Test for phenols}

Ferric chloride test

Fifty milligrams extract was dissolved with distilled water and added few drops of neutral 5\% ferric chloride solution. The form of a dark green color specified the existence of the phenolic compound [7].

\section{Test for flavonoids}

Lead acetate test

One milliliter of the crude extract added with two to three drops of dilute sodium hydroxide. A strong yellow color exhibited in the crude extract, which turns colorless with the inclusion of a few drops of dilute acid which signify the existence of flavonoid [8].

\section{Test for reducing sugars}

Plant extract $(1 \mathrm{ml})$ was added with $1 \mathrm{ml}$ of each Fehling's solution $\mathrm{A}$ and $\mathrm{B}$ and boiled in a water bath. The presence of red precipitate specified the existence of reducing sugars [9].

\section{Test for tannin}

Gelatin test

One milliliter of plant extract was added with $5 \mathrm{ml}$ of distilled water and $1 \%$ of gelatine was mixed into the test tube. Afterward, $10 \%$ Sodium chloride $(\mathrm{NaCl})$ solution was added. The appearance of a white precipitate displayed the existence of tannin [10].

\section{Test for anthraquinones}

Ammonium hydroxide test

The plant extract $(10 \mathrm{mg})$ was dissolved in isopropyl alcohol and a few drops of concentrated ammonium hydroxide solution were added. After 2 min a form of red color indicated the existence of anthraquinones [11].

\section{Test for terpenoids}

The plant extract ( $5 \mathrm{ml}$ ) added with chloroform $(1 \mathrm{ml})$, and then placed in a water bath and $3 \mathrm{ml}$ of concentrated Sulphuric acid $\left(\mathrm{H}_{2} \mathrm{SO}_{4}\right)$ was included ultimately boiled on a water bath. The presence of grey color specified the existence of terpenoids [11].

\section{Test for amino acids}

Biuret test

The plant extract $(2 \mathrm{ml}$ ) was added with one drop of $2 \%$ copper sulfate solution. Afterward, $1 \mathrm{ml}$ of $95 \%$ ethanol and few Potassium hydroxide $(\mathrm{KOH})$ pellets were added. The presence of a pink color formation confirms the existence of amino acids [12].

\section{Test for steroids}

Salkowski test

Plant extract $(2 \mathrm{ml})$ was added with $2 \mathrm{ml}$ of chloroform and $2 \mathrm{ml}$ of $\mathrm{H}_{2} \mathrm{SO}_{4}$. The presence of a reddish-brown ring junction confirms the existence of steroids [13].

\section{Determination of total phenolic content}

Folin-Ciocalteu assay method was used for the determination of the total phenol content [14]. Briefly, in a volumetric flask (25 ml), $1 \mathrm{ml}$ of the extract was added with $9 \mathrm{ml}$ of distilled water then $1 \mathrm{ml}$ of FolinCiocalteu phenol reagent was added and shaken well. Ten milliliter of $7 \%$ sodium carbonate $\left(\mathrm{Na}_{2} \mathrm{CO}_{3}\right)$ was added to the reaction mixture after $10 \mathrm{~min}$. Afterward, the solution was incubated for $60 \mathrm{~min}$ at room temperature and the absorbance was measured at $550 \mathrm{~nm}$ with a UV visible spectrophotometer. Gallic acid at different concentrations $(0.2,0.4,0.6,0.8$, and $1.0 \mathrm{mg} / \mathrm{ml})$ was used as a standard. In the same manner, as delineated earlier and the results were expressed as $\mathrm{mg}$ of gallic acid equivalent (GAE)/g of extract.

\section{Determination of tannin content}

The total tannin content was firm by Folin-Ciocalteu method with slight variations [15]. Approximately, $0.1 \mathrm{ml}$ of the plant extract was added to a volumetric flask $(10 \mathrm{ml})$ comprising $7.5 \mathrm{ml}$ of distilled water and $0.5 \mathrm{ml}$ of Folin-Ciocalteu phenol reagent. One milliliter of $35 \% \mathrm{Na}_{2} \mathrm{CO}_{3}$ solution diluted with $10 \mathrm{ml}$ of distilled water. The reaction mixture was stirred well and kept at room temperature for $15 \mathrm{~min}$. The different concentrations $(0.2,0.4,0.6,0.8$, and $1.0 \mathrm{mg} / \mathrm{ml})$ of gallic acid standard solutions were prepared in the same manner as described earlier. The absorbance was determined against the blank at $725 \mathrm{~nm}$. The content of tannin was calculated as mg of tannic acid equivalents (TAE)/g of plant extract.

\section{Antioxidant activity \\ Hydroxyl radical scavenging assay}

Hydroxyl radical scavenging activity of the extracts was examined as stated by the earlier described technique [16]. The reaction mixture enclosed $1 \mathrm{ml}$ of various concentration of extracts $(2-10 \mathrm{mg} / \mathrm{ml})$, $1.0 \mathrm{ml}$ of iron-ethylenediamine tetra acetic acid (EDTA) solution (1.5 mM ferrous ammonium sulfate and $0.1 \mathrm{mM}$ EDTA), $0.018 \%$ EDTA $0.5 \mathrm{ml}$, DMSO $1.0 \mathrm{ml}(0.85 \%$ in $0.1 \mathrm{~mol} / \mathrm{l}$ phosphate buffer $\mathrm{pH} 7.4$ ), and $0.22 \%$ ascorbic acid $0.5 \mathrm{ml}$. The firmly enclosed reaction mixture contained test tubes were heated in a water bath at 70$80^{\circ} \mathrm{C}$ for $20 \mathrm{~min}$, this process was ended by the addition of ice-cold trichloroacetic acid (TCA) $(1.0 \mathrm{ml})(17.5 \%)$. Eventually, Nash reagent $3.0 \mathrm{ml}(75.0 \mathrm{~g}$ of ammonium acetate, $3.0 \mathrm{ml}$ of glacial acetic acid, and $2.0 \mathrm{ml}$ of acetylacetone and distilled water was added to a total volume of $1 \mathrm{l}$ ) was added and kept room temperature for $15 \mathrm{~min}$ for color change. The formation of yellow color developed was measured at $412 \mathrm{~nm}$ and gallic acid was used as a standard. The IC50 value for the extract and standard preparation was assessed using the following formula,

$\%$ scavenging $/$ Inhibition $=[$ Absorbance of control-Absorbance of test sample/Absorbance of control] $\times 100$ 
Ferric reducing antioxidant potential (FRAP) assay

The reducing power capability of the extracts was investigated as stated by the earlier described method [17]. In brief, $1.0 \mathrm{ml}$ of different concentrations of extracts $(20 \mu \mathrm{g} / \mathrm{ml}-100 \mu \mathrm{g} / \mathrm{ml}), 2.5 \mathrm{ml}$ of $1 \%$ potassium ferricyanide, and $2.5 \mathrm{ml}$ of $0.2 \mathrm{~mol} / \mathrm{L}$ sodium phosphate buffer were mixed well and incubated at $60^{\circ} \mathrm{C}$ for $20 \mathrm{~min}$. Afterward, the reaction was ended by the addition of $2.5 \mathrm{~mL}$ of $10 \%$ trichloroacetic acid, followed by centrifugation at $2000 \mathrm{rpm} / \mathrm{min}$ for $15 \mathrm{~min}$. Ultimately, the upper layer $(2.5 \mathrm{ml})$ was mixed with deionized water $(2.5 \mathrm{ml})$ and $0.5 \mathrm{ml}$ of $0.1 \%$ ferric chloride. Ascorbic acid was used as standard and the absorbance was measured at $700 \mathrm{~nm}$.

\section{2,2-diphenyl-2-picrylhydrazyl (DPPH) radical scavenging assay} The capability of the ethanolic extract of $C$. halicacabum to scavenge the DPPH free radical was determined according to the previously described method [18] with minor modification. The extract at different concentrations $(20 \mu \mathrm{g} / \mathrm{ml}, 40 \mu \mathrm{g} / \mathrm{ml}, 60 \mu \mathrm{g} / \mathrm{ml}, 80 \mu \mathrm{g} / \mathrm{ml}$, and $100 \mu \mathrm{g} / \mathrm{ml})$ was prepared. Each sample $(0.5 \mathrm{ml})$ was prepared and mixed with $0.5 \mathrm{ml}$ of $1 \mathrm{mM}$ DPPH solution in ethanol. The reaction mixture was kept at room temperature for $20 \mathrm{~min}$. The reduction ability of DPPH radicals was measured by decreased induction of antioxidants in their absorbance at $517 \mathrm{~nm}$. The ascorbic acid was used as a standard and similar concentrations were prepared as the test solutions. The difference in absorbance between the test and the control (DPPH in ethanol) was determined and expressed as \% scavenging of DPPH radical. The ability to scavenge the DPPH radical was measured using the following equation.

\section{$\% \mathrm{DPPH}$ radical scavenging activity $=\{(\mathrm{A} 0-\mathrm{A} 1) / \mathrm{A} 0\} \times 100$}

where $A_{0}$ is the absorbance of the control, and $A_{1}$ is the absorbance of the extract/standard. Afterward, the \% of inhibition was calculated against concentration, and from the graph $\mathrm{IC}_{50}$ was determined.

\section{Fourier transform infrared (FT-IR) analysis}

FTIR spectrophotometer is possibly the most efficient tool to find the types of chemical bonds and functional groups existing in compounds. Dried powder of $C$. halicacabum ethanolic extract was used for FTIR analysis. The powdered ethanolic extract (10 mg) was placed in $100 \mathrm{mg}$ of potassium bromide $(\mathrm{KBr})$ pellet, to prepare a translucent sample disc. The powdered sample was loaded on to FTIR spectroscope and the spectroscopy results were documented on an FTIR spectrometer alpha II Compact Bruker, with a scan range from 400 to $4000 \mathrm{~cm}^{-1}$.

\section{Antibacterial activity}

Test microorganism

The antibacterial properties of $C$. halicacabum extracts were examined against Gram-positive bacteria: Staphylococcus aureus, Enterococcus faecalis, and Gram-Negative bacteria: Moraxella sp., Escherichia coli, and Proteus mirabilis. The bacterial strains were obtained from the Department of microbiology, Alagappa University, Karaikudi.

\section{Antibacterial assay}

The disk diffusion method was used to examine the antibacterial activity of the $C$. halicacabum extract. The bacterial strains were inoculated in the nutrient broth under aseptic conditions and incubated at $37^{\circ} \mathrm{C}$ for $24 \mathrm{~h}$. After the incubation period, the test bacteria were inoculated on the nutrient agar (HiMedia) plate using a sterile cotton swab. The different concentrations of petroleum ether, chloroform, acetone, ethanol, and aqueous extracts $(200,400,600$, and $800 \mu \mathrm{g} / \mathrm{disc})$ were loaded on the $6 \mathrm{~mm}$ sterilized discs (Hi Media,) to measure the dosedependent activity of the extracts. Cefepime ( $30 \mathrm{mcg} / \mathrm{disc})$ was used as a positive control and the individual solvents were used as a negative control. Afterward, the Petri plates were kept at incubator $\left(37^{\circ} \mathrm{C}\right)$ for $18-$ $24 \mathrm{~h}$. The zones of inhibition and the mean diameter were documented.

\section{Statistical analysis}

Each experiment of quantitative phytochemical analysis and antibacterial activity was conducted in three replicates. Statistical analysis was performed by SPSS version 20.0 (SPSS Inc. Chicago, IL). Differences between means were verified using one-way ANOVA and the least significant difference test. The significance levels were considered at $\mathrm{p} \leq 0.05$.

\section{RESULTS AND DISCUSSION}

\section{Callus induction}

Callus induction was detected from cut margins of stem explants of C. halicacabum after 2 weeks of incubation, cultured on MS medium supplemented with auxins, namely, 2, 4-D, IAA, indolebutyric acid (IBA), and NAA (0.5-2.0 mg/l) along with BA (0.5 mg/l), under a partial incubation in dark (Table 1). Initial responses such as stem expand subsequently swelling of explant were observed from the $6^{\text {th }}$ day of the culture period (Fig. 1a-d). Among various treatments, 2, 4-D along with BA gave the best callus initiation and proliferation, followed by NAA, IAA, and IBA (Table 1, Fig. 1b and e). Contingent on the concentration and combination of plant growth regulators (PGR) benefitted, an extensive range of variation in the frequency of callus formation and nature of callus was observed. The fresh weight and dry weight of callus biomass for stem explants of $C$. halicacabum are shown in Table 1. The highest fresh weight was achieved on $0.5 \mathrm{mg} / \mathrm{l} \mathrm{BA}$ and $0.7 \mathrm{mg} / \mathrm{l} 2$, 4-D. NAA at lower and higher concentrations produced light yellow to brown friable or nodular callus from stem explants, which were failed to respond further (Table 1). In contrast, NAA was reported to develop higher callus induction [19]. Medium containing $0.7 \mathrm{mg} / \mathrm{l} \mathrm{IAA}$ and $0.5 \mathrm{mg} / \mathrm{l} \mathrm{BA}$ produced yellowish green compact callus was obtained from stem explants, whereas IBA $(0.7 \mathrm{mg} / \mathrm{l})$ with BA $(0.5 \mathrm{mg} / \mathrm{l})$ produced dark brown callus with rooting. Likewise, Thaniarasu et al. [20] proposed that the modified callus did not form adventitious roots on medium with auxins but only with cytokinins; therefore, it is suggested that cytokinin has a stimulating effect on root formation from callus. The highest frequency (78\%) of well developed,
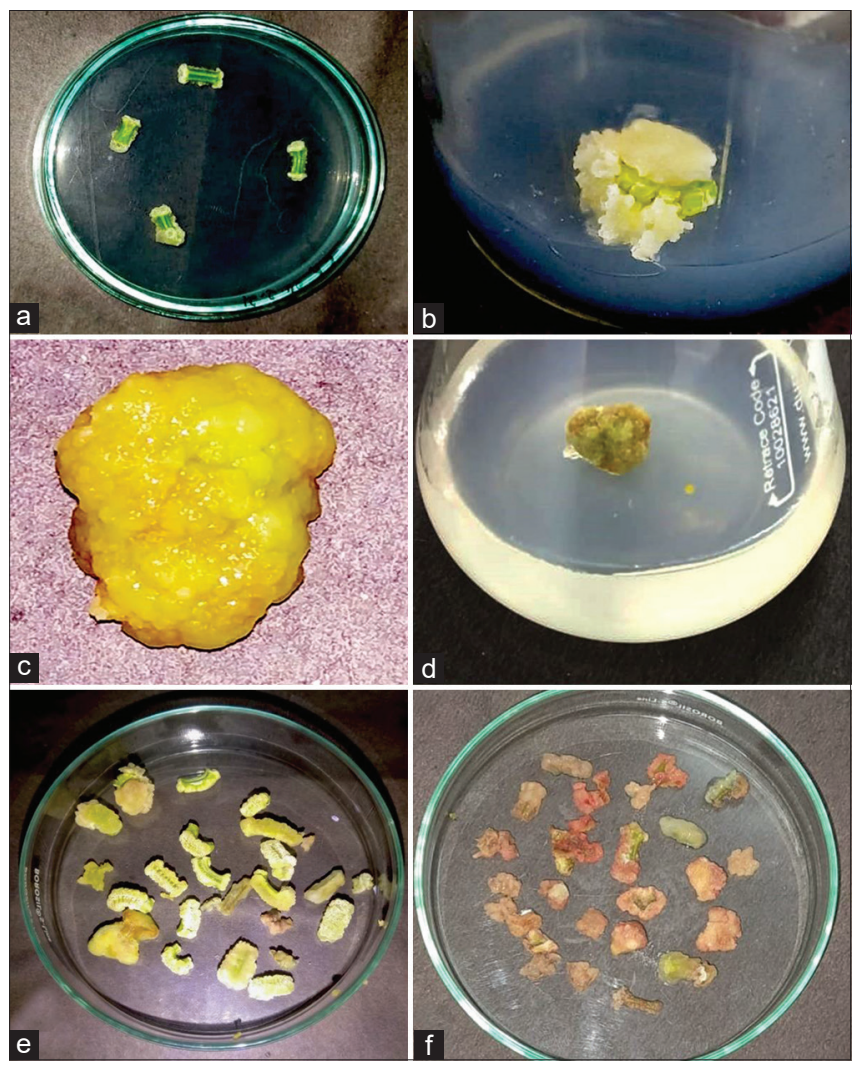

Fig. 1: Callus induction and proliferation of Cardiospermum halicacabum L. (a) Stem explant, (b-d) Callus induction on MS + 2,4-D (0.7 mg/l) + BA (0.5 mg/l), (e) Callus fresh weight (407 mg), (f) Callus dry weight $(99 \mathrm{mg})$ 
Table 1: Callus induction from leaf and internode explants of $C$. halicacabum cultured on MS medium supplemented with different concentrations of auxins with BA, after 4 weeks of culture

\begin{tabular}{|c|c|c|c|c|}
\hline PGR's (mg/l) & $\%$ of response & Callus fresh weight mg/explant & Callus dry weight mg/explant & Texture of callus \\
\hline Control & $00.0 \pm 0.0$ & $00.0 \pm 0.0$ & $00.0 \pm 0.0$ & $00.0 \pm 0.0$ \\
\hline \multicolumn{5}{|l|}{$2,4-D+B A(0.5)$} \\
\hline 0.5 & $63.0 \pm 1.5$ & $335.4 \pm 2.45$ & $84.5 \pm 0.59$ & GC \\
\hline 0.7 & $78.0 \pm 1.3$ & $407.6 \pm 1.20$ & $99.0 \pm 1.30$ & GC \\
\hline 1.0 & $58.0 \pm 1.3$ & $326.6 \pm 0.90$ & $79.0 \pm 0.53$ & GC \\
\hline 2.0 & $44.0 \pm 1.6$ & $278.2 \pm 1.40$ & $63.0 \pm 0.56$ & GF \\
\hline \multicolumn{5}{|l|}{$\mathrm{NAA}+\mathrm{BA}(0.5)$} \\
\hline 0.7 & $55.0 \pm 2.2$ & $348.3 \pm 1.33$ & $70.6 \pm .40$ & GYF \\
\hline 1.0 & $43.0 \pm 1.5$ & $308.9 \pm 0.38$ & $66.8 \pm 0.53$ & YGC \\
\hline 2.0 & $32.0 \pm 1.3$ & $230.2 \pm 0.41$ & $54.6 \pm 0.90$ & YF \\
\hline \multicolumn{5}{|l|}{$\mathrm{IAA}+\mathrm{BA}(0.5)$} \\
\hline 0.5 & $32.0 \pm 1.3$ & $160.7 \pm 0.68$ & $46.4 \pm 0.71$ & YF \\
\hline 0.7 & $34.0 \pm 1.6$ & $228.4 \pm 0.49$ & $47.5 \pm 0.52$ & YGC \\
\hline 1.0 & - & - & - & - \\
\hline 2.0 & - & - & - & - \\
\hline 0.5 & $33.0 \pm 1.5$ & $140.4 \pm 0.21$ & $34.0 \pm 0.68$ & $\mathrm{BCC}$ \\
\hline 0.7 & $35.0 \pm 1.6$ & $124.4 \pm 0.39$ & $34.2 \pm 0.76$ & BCC \\
\hline 1.0 & - & - & - & - \\
\hline 2.0 & - & - & - & - \\
\hline
\end{tabular}

Values are mean \pm S.E. from seven replicates per treatment and all the experiments were repeated thrice. Means followed by the same letters in each column are not significantly different ( $p=0.05$ ) using Duncan's multiple range test. GC: Green Compact, BCC: Brownish Compact, GYF: Greenish Yellow Friable, YF: Yellow friable, GF: Green friable, YGC: Yellowish Green Compact,-: no response, PGR: Plant growth regulators, NAA: Naphthalene acetic acid, IAA: Indole-3 acetic acid, BA: Benzyl adenine, IBA: Indolebutyric acid.

dark green organogenic callus was induced from stem explant on MS medium supplemented with $0.7 \mathrm{mg} / \mathrm{l} 2$, 4-D, and $0.5 \mathrm{mg} / \mathrm{l} \mathrm{BA} \mathrm{(Fig.} 1 \mathrm{~b}$ and e). Lower concentrations of 2, 4-D (0.5-1.0 mg/l) along with BA $(0.5 \mathrm{mg} / \mathrm{l})$ formed profuse amount of callus in contrast to higher concentrations (Table 1). Among the different concentrations of auxin tested, 2, 4-D with BA proved to be the best for the high frequency of greenish compact callus induction. Previous investigations proved the same [21-23]. All the callus cultures were sub-cultured every 15 days onto a fresh medium containing the same PGR composition. Maximum calli were induced and developed as light yellow in color and become green compact organogenic callus in 4 weeks.

\section{Screening and qualitative comparison of phytochemicals}

Both the crude and callus extracts were subjected to preliminary chemical tests 18 to detect the presence and absence of various phytochemicals such as alkaloids, flavonoids, steroids, triterpenes, saponins, phenolics, and tannins (Table 2). The phytochemical constituents greatly differed among the tested solvents in both wild stem extract and in vitro callus extract. This is a sign of solvents varied extracting abilities for phytochemicals [24].

\section{FT-IR analysis}

The results of FTIR spectra confirmed the presence of functional groups in wild stem extract of $C$. halicacabum with peaks at $3329.72 \mathrm{~cm}^{-1}$ (alcohols, phenols), $2973.28 \mathrm{~cm}^{-1}$ (alkanes), $2927.64 \mathrm{~cm}^{-1}$ (amine salts), $1655.88 \mathrm{~cm}^{-1}$ (alkanes, amines), $1450.96 \mathrm{~cm}^{-1}$ (Alkanes), $1417.42 \mathrm{~cm}^{-1}$ (alcohol), $1379.87 \mathrm{~cm}^{-1}$ (phenols, nitrogen groups, alcohols, carboxylic acids, esters, and ethers), $1275.39 \mathrm{~cm}^{-1}$ (alkyl esters), $1086.75 \mathrm{~cm}^{-1}$ (anhydride), and $661.42 \mathrm{~cm}^{-1}$ (acid chlorides and alkanes) (Fig. 2 and Table 3), followed by callus ethanolic extracts with peaks at $3388.01 \mathrm{~cm}^{-1}$ (alcohols, phenols), $2974.38 \mathrm{~cm}^{-1}$ (Carboxylic acid), $2924.01 \mathrm{~cm}^{-1}$ (carboxylic acid and amine salts), $2138.50 \mathrm{~cm}^{-1}$ (alkanes and amines), $1706.78 \mathrm{~cm}^{-1}$ (alkanes and amides), $1362.76 \mathrm{~cm}^{-1}$ (alcohol), $1274.01 \mathrm{~cm}^{-1}$ (amines, phenols, nitrogen groups, alcohols, carboxylic acids, esters, and ethers), $1087.08 \mathrm{~cm}^{-1}$ (alkyl esters), $880.01 \mathrm{~cm}^{-1}$ (anhydride), and $670.66 \mathrm{~cm}^{-1}$ (acid chlorides and alkanes) (Fig. 3 and Table 4). The FT-IR spectrum of wild stem and callus ethanolic extracts confirms the presence of functional groups for phenolics and flavonoids, which are widely reported for their antioxidant potential. Major groups
Table 2: Qualitative analysis of ethanolic extracts of stem and callus of $C$. halicacabum

\begin{tabular}{lll}
\hline Phytochemicals & Callus extract & Plant extract \\
\hline Steroids & - & + \\
Terpenoids & + & + \\
Reducing sugar & - & - \\
Alkaloids & + & + \\
Tannins & + & + \\
Flavonoids & + & + \\
Saponins & - & + \\
Phenolic compounds & + & + \\
Amino acids & - & + \\
Anthraquinones & - & - \\
\hline
\end{tabular}

(+): Present, (-): Absent.

are present in the callus extract. Flavonoids and phenolic acids have antibacterial, antifungal, antiviral, hepatoprotective, immunomodulating, and anti-inflammatory properties [25]. Major peaks were observed at $3388.01 \mathrm{~cm}^{-1}$ that possibly designated to the $\mathrm{O}-\mathrm{H}$ stretching vibrations of $\mathrm{O}-\mathrm{H}$ Alcohol. Consequently, the present investigation results show that the primary functional group presents in C. halicacabum is $\mathrm{O}-\mathrm{H}$ Alcohol. O-H, group possibly specifies the higher potential toward inhibitory activity against microorganisms. Like a higher antimicrobial activity of ethanol extracts of the leaf has been previously established by some authors [26]. Through the FT-IR spectrum, we identified the functional groups from the given extract. Many researchers employed the FT-IR spectrum as a tool for observing closely associated plants and other organisms. The outcomes of the present investigation improved an innovative phytochemical marker to find the medicinally significant plant.

\section{Determination of total phenol}

The total phenolic content for C. halicacabum $(1.0 \mathrm{mg} / \mathrm{ml})$ was calculated from the standard graph of gallic acid with the standard curve equation, $\mathrm{Y}=0.97 \times-0.176, \mathrm{R}^{2}=0.999$ (Fig. 4). The total phenolic content in aqueous extract of in vivo plant and in vitro callus was $80.46 \mathrm{mg} \mathrm{GAE} / \mathrm{g}$ dry weight and $76.4 \mathrm{mg} \mathrm{GAE} / \mathrm{g}$ dry weight, respectively (Fig. 5). At present, plant materials rich in phenolics are used in the 


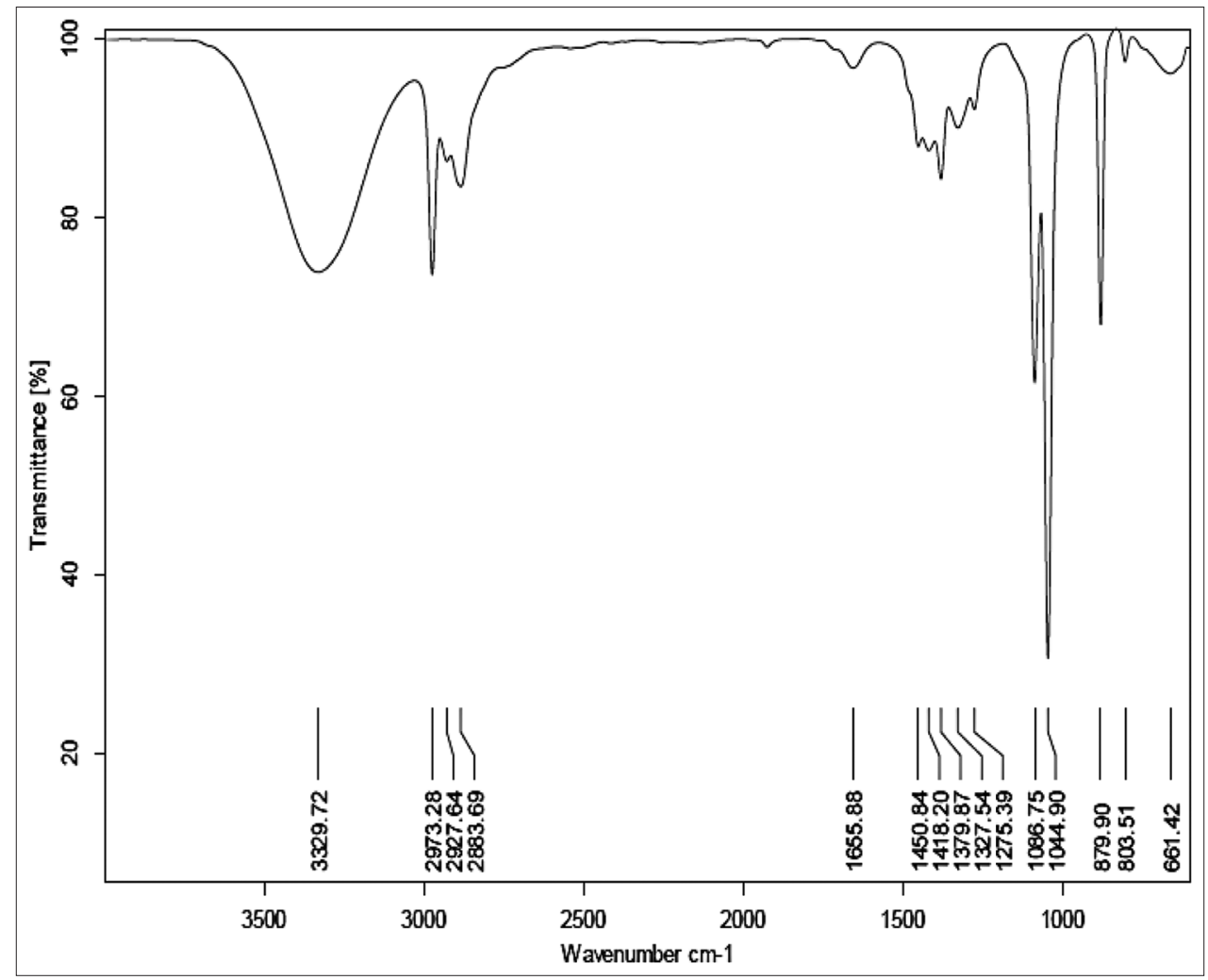

Fig. 2: Fourier transform infrared spectrum of the ethanolic extract of Cardiospermum halicacabum

Table 3: FT-IR analysis of in vivo stem ethanolic extract of C. halicacabum L

\begin{tabular}{llll}
\hline Frequency & $\begin{array}{l}\text { Frequency } \\
\text { range }\end{array}$ & Bond & $\begin{array}{l}\text { Functional group } \\
\text { name }\end{array}$ \\
\hline 3329.72 & $\sim 3400-3300$ & O-H Stretch & Aromatics \\
2973.28 & $\sim 2950-2800$ & C-H Stretch & Alkanes \\
2927.64 & $\sim 3400-2400$ & O-H Stretch & Carboxylic acids \\
2883.69 & $\sim 2950-2800$ & C-H Stretch & Alkanes \\
1655.88 & $1690-1640$ & $\mathrm{R}_{2}$ C=N-R Stretch & Imines \\
1450.84 & $1550-1490$ & -NO (Aromatic) & Nitro groups \\
1418.20 & $1440-1400$ & O-H Bend & Carboxylic acids \\
1379.87 & $1400-1000$ & C-F Stretch & Alkyl halides \\
1327.54 & $1360-1250$ & C-N Stretch (Aryl) & Amines \\
1275.39 & $1300-1100$ & C-C Stretch & Ketones \\
1086.75 & $1090-810$ & PH Bend & Phosphines \\
1044.90 & $\sim 1400-1000$ & C-F Stretch & Alkyl halides \\
879.90 & $\sim 880$ & C-H Bend(meta) & Aromatics \\
803.51 & $850-800$ & C-H Bend(para) & Aromatics \\
661.42 & $730-550$ & C-Cl Stretch & Acid chlorides \\
\hline
\end{tabular}

FT-IR: Fourier transform infrared.

food industry because they decrease the oxidative degradation of lipids and maintain the quality and nutritional value of food. We determined that the total phenolic content was slightly more in the aqueous extract compared to the methanol and ethyl acetate extract [27].

\section{Determination of total tannin content}

The concentration of total tannin in C. halicacabum samples was derived from standard curve of tannic acid ranging from 0.2 to $1.0 \mathrm{mg} / \mathrm{ml}(y=0.97 \times-0.086$; $\mathrm{R}=0.9932)$ (Fig. 6). The obtained values for the concentration of tannin contents are measured as mg of TAE/g of extract. The maximum percentage of tannins was determined at 78.03 in wild stem ethanol extracts followed by 75.22 in callus extract (Fig. 7). Tannins possess high radical scavenging capability can be extensively found in plants and have several positive results on human health.
Table 4: FT-IR analysis of ethanolic callus extract of C. halicacabum $\mathrm{L}$.

\begin{tabular}{llll}
\hline Frequency & $\begin{array}{l}\text { Frequency } \\
\text { range }\end{array}$ & Bond & $\begin{array}{l}\text { Functional } \\
\text { Group Name }\end{array}$ \\
\hline 3388.01 & $\sim 3400-3300$ & O-H stretch & Alcohols \\
2974.38 & $\sim 3400-2400$ & O-H stretch & Carboxylic acid \\
2924.01 & $\sim 3400-2400$ & O-H stretch & Carboxylic acid \\
2138.50 & $\sim 2150-1800$ & C, C triple bond stretch & Alkynes \\
1706.78 & $1730-1700$ & C=O stretch & Carboxylic acid \\
1653.34 & $1680-1630$ & C=O stretch & Amides \\
1420.63 & $1440-1400$ & O=H bend & Carboxylic acid \\
1362.76 & $1390-1300$ & -NO (aliphatic) & Nitro group \\
1274.01 & $1360-1250$ & C-N stretch (aryl) & Amines \\
1225.35 & $1260-1000$ & C=0 stretch & Alcohols \\
1087.08 & $1260-1000$ & C=0 stretch & Alcohols \\
1046.28 & $1260-1000$ & C=O stretch & Alcohols \\
880.01 & 880 & C-H bend (meta) & Aromatics \\
803.58 & $850-800$ & C-H bend (para) & Aromatics \\
670.66 & $715-685$ & C-H bend (mono) & Aromatics \\
\hline
\end{tabular}

FT-IR: Fourier transform infrared.

\section{Antioxidant activity}

Hydrogen peroxide radical scavenging activity

The hydroxyl radical is an extremely reactive free radical formed in the biological organization. It is as main active oxygen gathering radicals developed from the reaction of several hydroperoxides with transition metal ions and it is proficient in damaging about every molecule found in the living system causing lipid peroxidation and harmful to the biological system [28]. The higher hydroxyl radical scavenging activity was delivered at the concentration of $1000 \mu \mathrm{g} / \mathrm{ml}$. The $C$. halicacabum showed higher scavenging activity shown in Fig. 8. Each concentration of the extracts display hydroxyl radical scavenging activity was increased with the increasing concentration of the extracts. Significantly lower IC50 values were observed in comparison to in vivo grown stem and in vitro raised callus. It is found that IC50 values of the stem extracts of $C$. halicacabum are $306 \mu \mathrm{g} / \mathrm{ml}$ and $286 \mu \mathrm{g} / \mathrm{ml}$ in callus extract respectively (Fig. 8). 


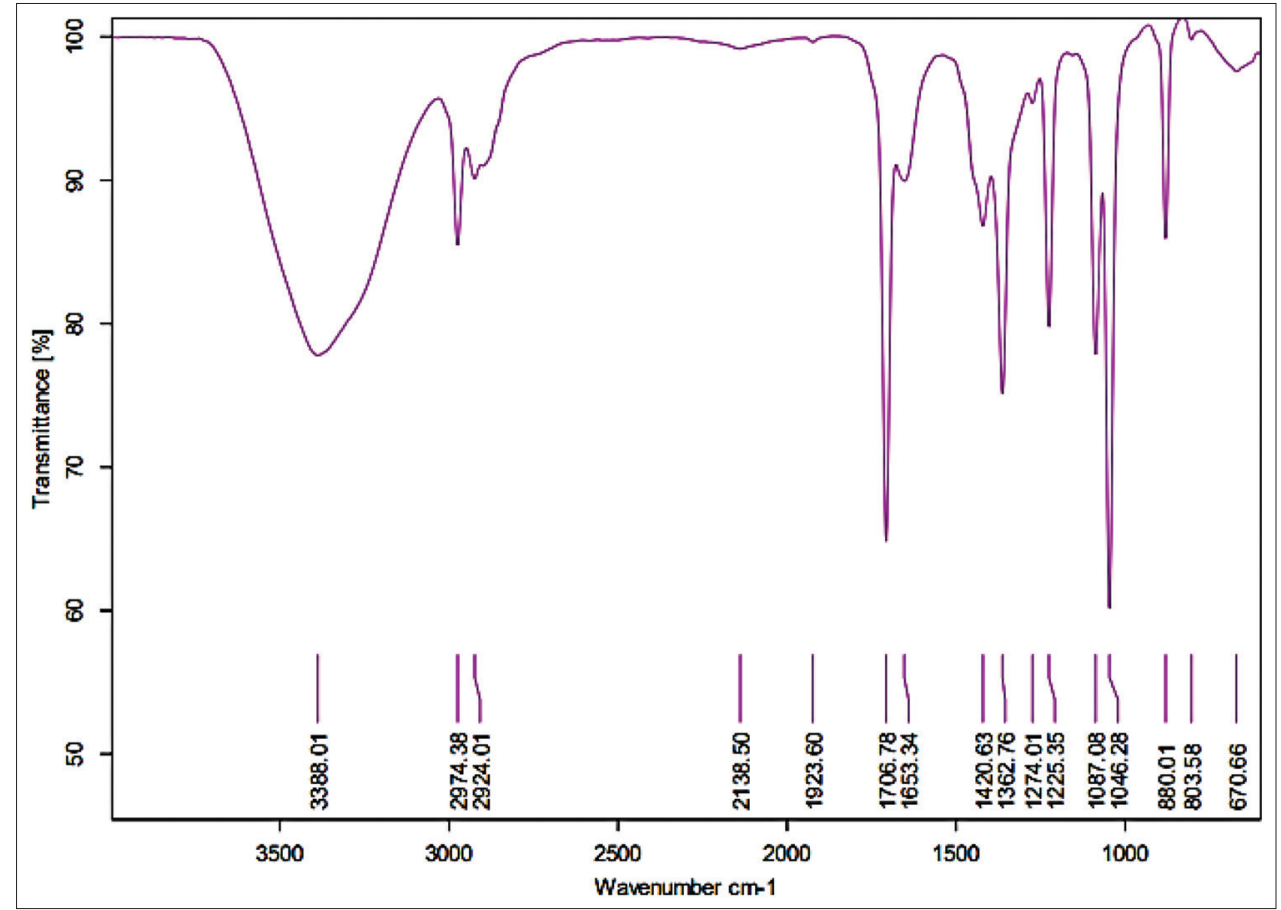

Fig. 3: Fourier transform infrared Spectrum of ethanolic callus extract of Cardiospermum halicacabum

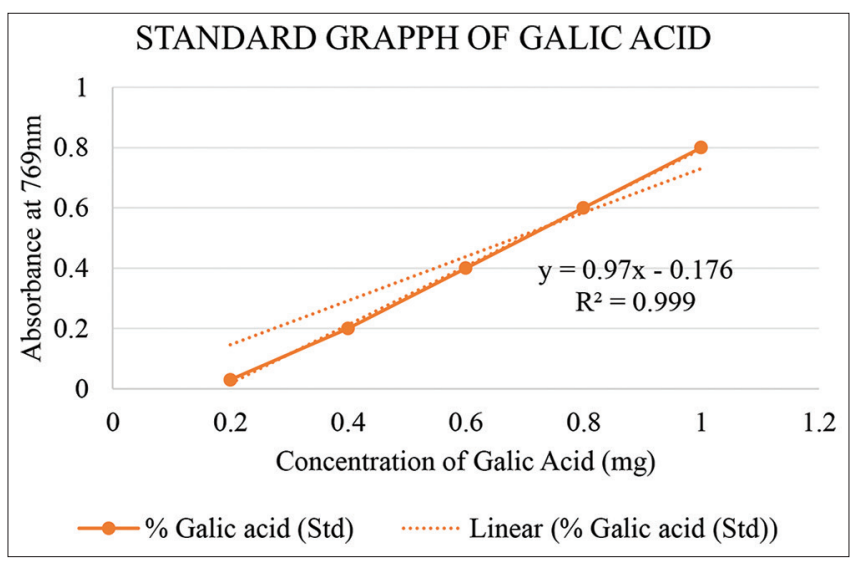

Fig. 4: Total phenolic content standard graph.

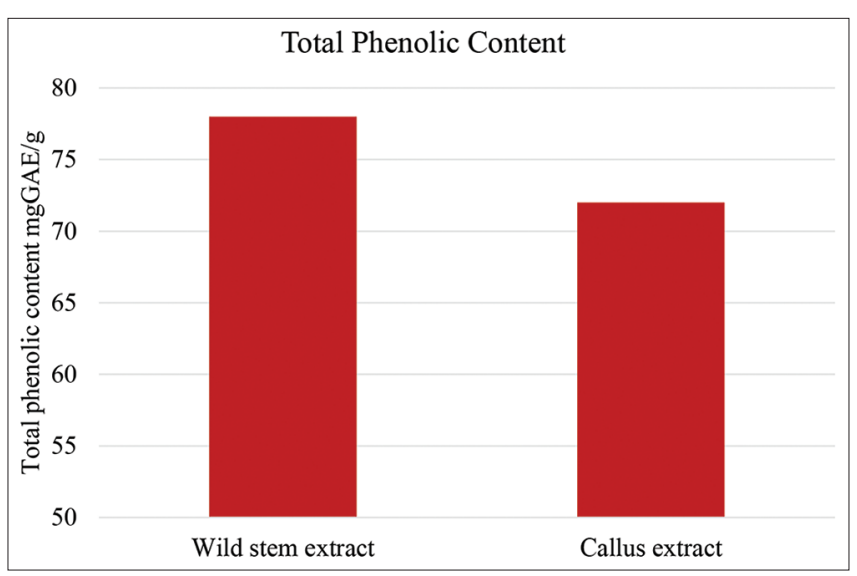

Fig. 5: Total phenolic content of Cardiospermum halicacabum

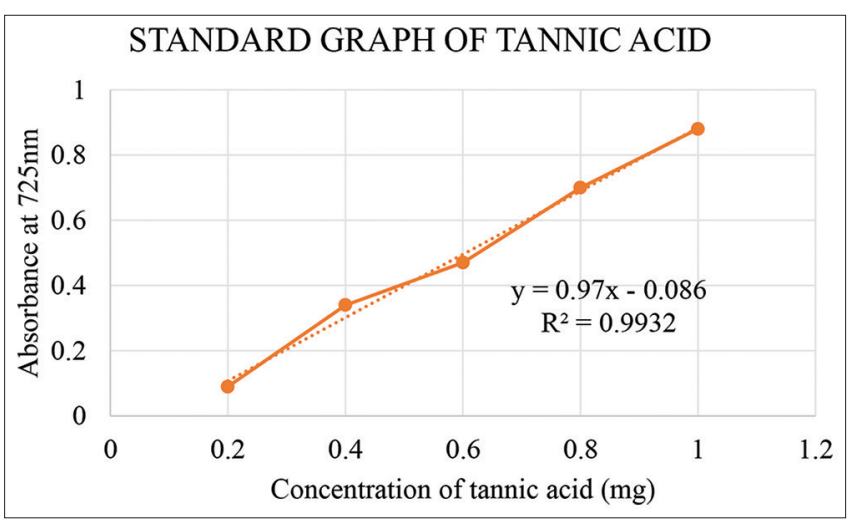

Fig. 6: Total tannin content standard graph

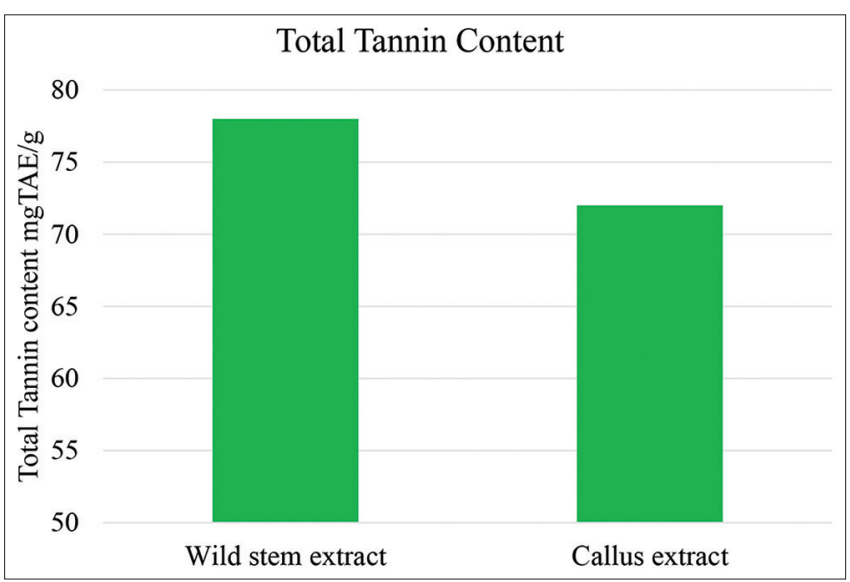

Fig. 7: Total tannin content of Cardiospermum halicacabum 
FRAP Assay

The reducing potential of the ethanolic extract of $C$. halicacabum wild stem and callus extracts was examined by the FRAP method to determine the direct electron transfer capability of the extract. The FRAP results were measured from a calibration graph which was linear over the calibration range with an $\mathrm{R}^{2}$ value of 0.9794 (Fig. 9) and the antioxidant ability of callus extract was found to be 225.29 $\mu \mathrm{moles} / \mathrm{mg}$ followed by wild stem extract $424 \mu \mathrm{moles} / \mathrm{mg}$. The reducing capacity of the $C$. halicacabum callus extract was similar to earlier studies on medicinal plants such as Albizia odoratissima [29] and Salvia officinalis [30].

\section{DPPH radical scavenging activity}

DPPH radical scavenging assay is a simple and extensively employed method to determine the quenching potential of antioxidants. DPPH is an unfirm radical forming purple in color and gets reduced in the presence of antioxidant to a non-radical firm form. The absorbance is measured at $517 \mathrm{~nm}$ by a UV spectrophotometer [31]. Ascorbic acid was used as a standard. It was noted, that the DPPH radical scavenging activity was increased with the increasing concentration of the extract. The IC50 value was estimated with the help of a graph and the lower IC50 gives better radical scavenging capability [32]. The IC50 value was calculated from a formerly developed standard curve (Fig. 10) and was found to be $206.54 \mu \mathrm{g} / \mathrm{ml}$. This least value of IC50 of the current study suggests that $C$. halicacabum callus extract has strong hydrogen donating capability. The examines performed on ethanolic plant extracts disclose that $C$. halicacabum displays DPPH radical scavenging capability in dose-dependent manner. The standard ascorbic acid exhibits higher radical scavenging compare to plant extract. The results were measured and expressed as ascorbic acid equivalent.

\section{Antibacterial activity}

The antibacterial activity of the various solvent extracts of $C$. halicacabum in vivo stem and in vitro callus against human pathogenic bacteria such as, S. aureus, E. faecalis, Moraxella sp., P. mirabilis, and $E$. coli was examined and assessed by the zone of inhibition

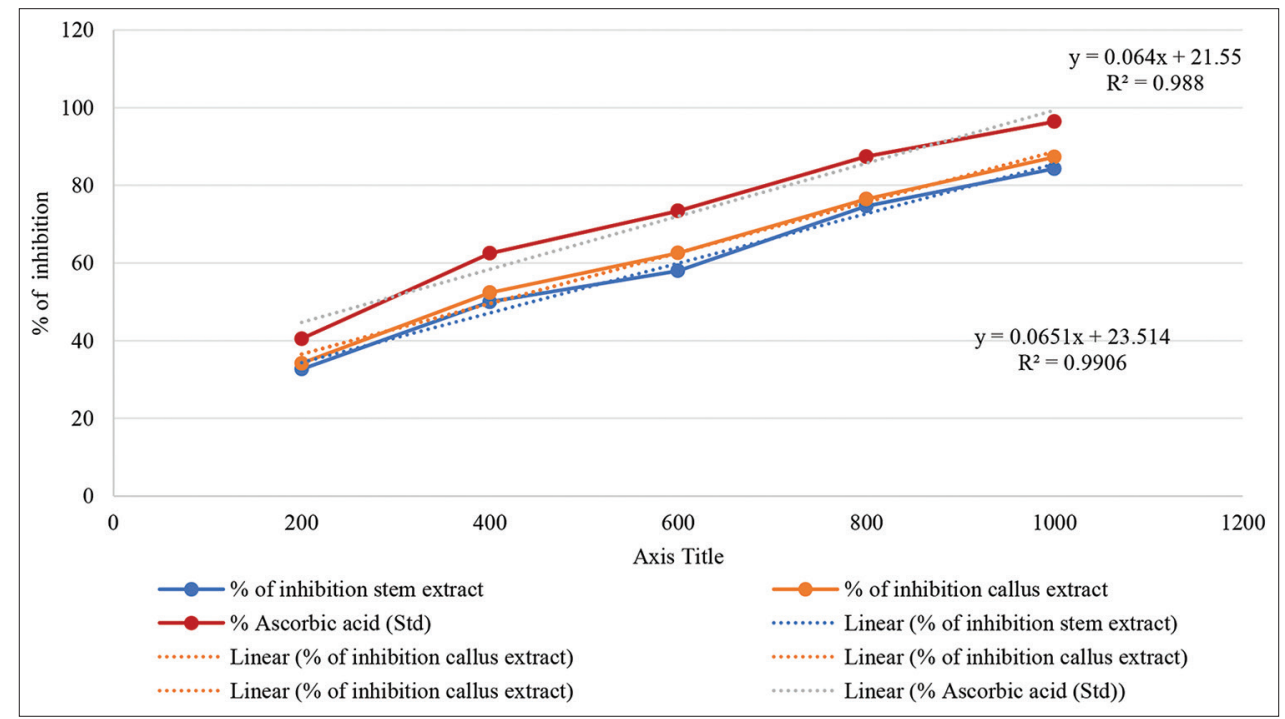

Fig. 8: Percentage of hydrogen peroxide inhibition in vivo stem and in vitro callus extract with respect to ascorbic acid standard

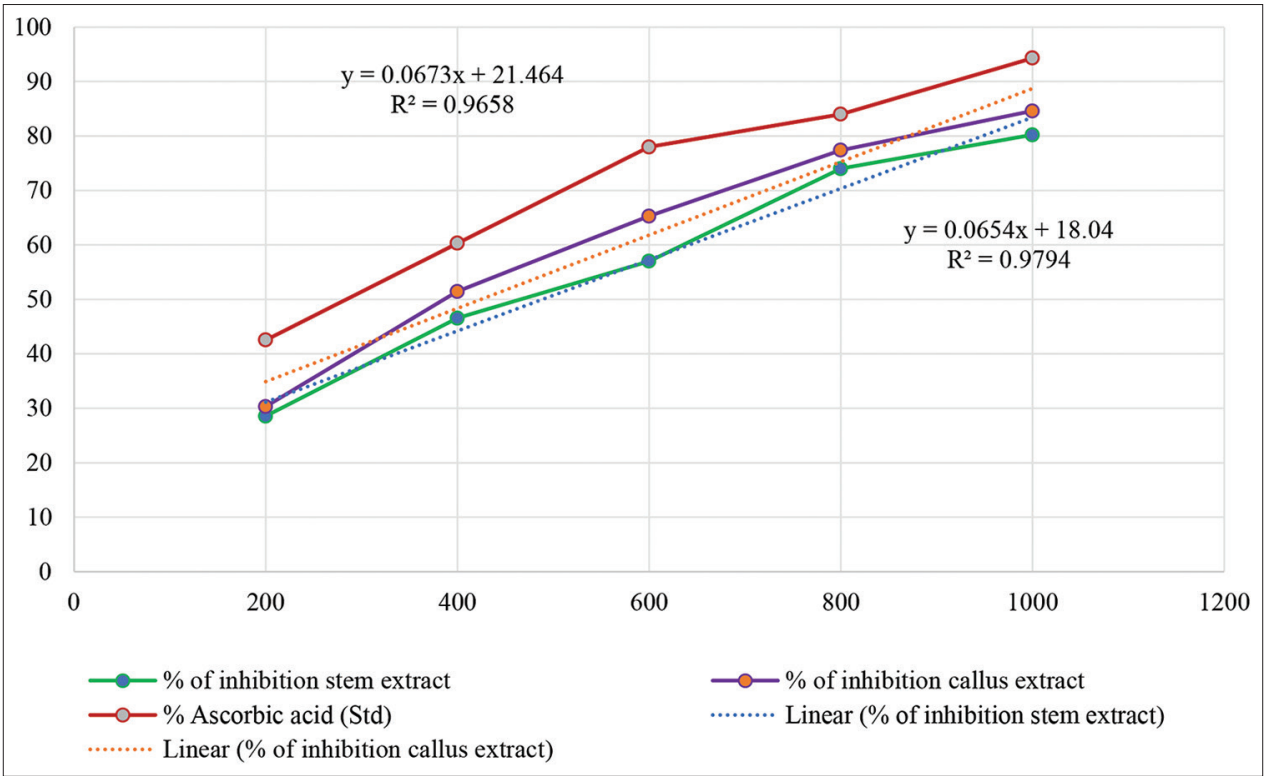

Fig. 9: Percentage of Ferric reducing antioxidant potential inhibition in in vivo stem and in vitro callus extract with respect to ascorbic acid standard 
in disc diffusion method. The ethanol extract exhibits significant antibacterial activity against all the tested bacteria. The action of different solvent extracts was comparable to the standard Cefepime. Among the different solvent extracts, petroleum ether and aqueous extracts showed lower antibacterial activity compared to other solvent extracts. The callus chloroform extracts displayed maximum activities against three of the strains; P. mirabilis $(10 \mathrm{~mm})$, Moraxella $\mathrm{sp}$ $(10 \mathrm{~mm})$, and $S$. aureus $(12 \mathrm{~mm})$, followed by stem extract $P$. mirabilis $(8 \mathrm{~mm})$, Moraxella sp $(10 \mathrm{~mm})$, and $S$. aureus $(10 \mathrm{~mm})$. The acetone callus extracts of maximum activities against two of the strains; $S$. aureus $(10 \mathrm{~mm})$ and E. faecalis $(8 \mathrm{~mm})$. The result of antibacterial activities is presented in Tables 5 and 6 . Among the various solvent extracts tested, the least antibacterial activity exhibited by aqueous extracts against all the tested strains. Among the different solvent extract tested, callus ethanolic extracts exhibited the highest activity of $17 \mathrm{~mm}(400 \mu \mathrm{l})$ inhibition zone against $S$. aureus this was followed by $13 \mathrm{~mm} \mathrm{E}$. coli, $14 \mathrm{~mm} \mathrm{E}$. faecalis, $8 \mathrm{~mm}$ P. mirabilis, and $10 \mathrm{~mm}$ inhibition zone against Moraxella sp. The in vivo stem extract showed the highest activity of $14 \mathrm{~mm}(400 \mu \mathrm{l})$ inhibition zone against $S$. aureus this was followed by $12 \mathrm{~mm} \mathrm{E}$. coli, $12 \mathrm{~mm} \mathrm{E}$. faecalis, $9 \mathrm{~mm} P$. mirabilis, and $10 \mathrm{~mm}$ inhibition zone against Moraxella sp (Tables 5 and 6). Among the different tested strains, S. aureus showed the most resistance to various solvents of extracts and $E$. coli showed moderate activity. The ethanolic extract was most effective when compared to the standard antibiotic Cefepime. The lowest activity of the extract is $3 \mathrm{~mm}$ against $E$. coli and P. mirabilis. The extracts at the lower concentrations displayed a maximum zone of inhibition compare to higher concentrations. In particular, $S$. aureus showed the fact that $C$. halicacabum ethanolic extract could be effective in chronic lung disorders and skin disorders, which are often induced by $S$. aureus. Based on the results, Gram-positive strains exhibited more effectiveness than Gram-negative strains, for the reason that

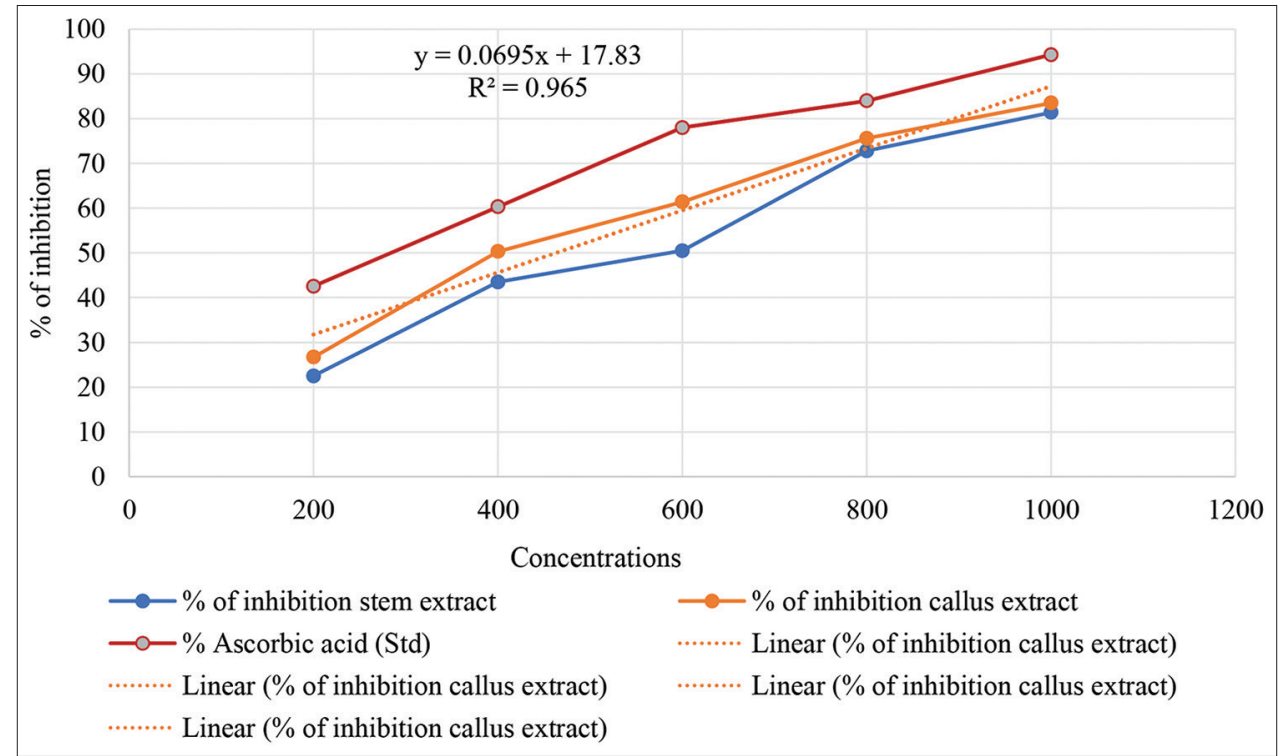

Fig. 10: Percentage of 2,2-diphenyl-2-picrylhydrazyl inhibition in vivo stem and in vitro callus extract with respect to ascorbic acid standard

Table 5: Zone of inhibition ( $\mathrm{mm}$ ) of Gram-ve and bacteria Gram+ve agents at various concentrations of different in vivo stem extracts of C. halicacabum and standard cefepime

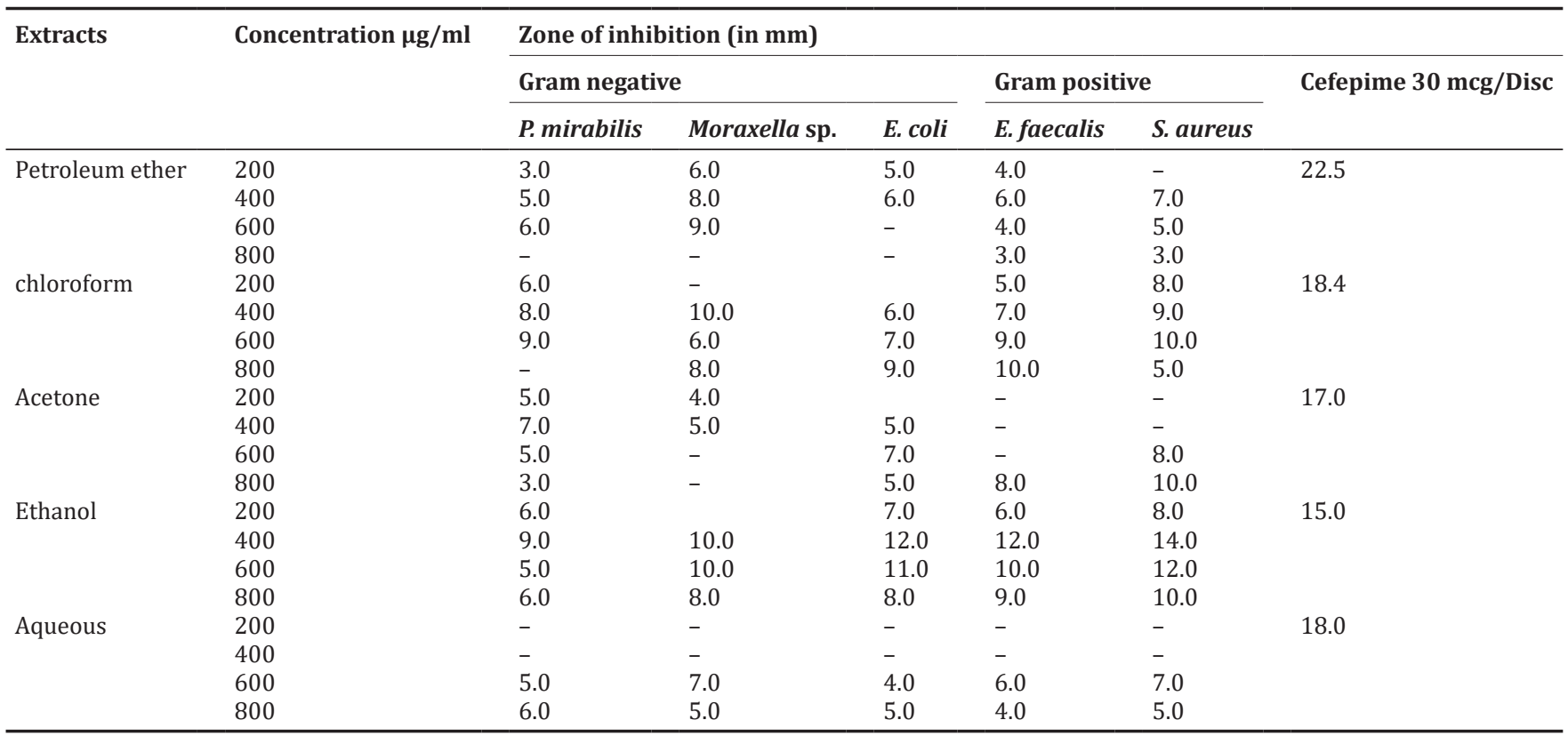

$(-)$ : No response. 
Table 6: Zone of inhibition ( $\mathrm{mm}$ ) of Gram-ve and bacteria Gram+ve agents at various concentrations of different in vitro callus extracts of C. halicacabum and standard cefepime

\begin{tabular}{|c|c|c|c|c|c|c|c|}
\hline \multirow[t]{3}{*}{ Extracts } & \multirow[t]{3}{*}{ Concentration $\mu \mathrm{g} / \mathrm{ml}$} & \multicolumn{6}{|c|}{ Zone of inhibition (in $\mathrm{mm}$ ) } \\
\hline & & \multicolumn{3}{|c|}{ Gram negative } & \multicolumn{2}{|c|}{ Gram positive } & \multirow[t]{2}{*}{ Cefepime $30 \mathrm{mcg} / \mathrm{Disc}$} \\
\hline & & P. mirabilis & Moraxella sp. & E. coli & E. faecalis & S. aureus & \\
\hline \multirow[t]{4}{*}{ Petroleum ether } & 200 & 3.0 & - & - & - & - & 20.5 \\
\hline & 400 & 5.0 & - & - & 6.0 & 8.0 & \\
\hline & 600 & 6.0 & 9.0 & 5.0 & 4.0 & 6.0 & \\
\hline & 800 & - & 7.0 & 4.0 & 3.0 & 5.0 & \\
\hline \multirow[t]{4}{*}{ chloroform } & 200 & 6.0 & - & & 5.0 & 8.0 & 18.5 \\
\hline & 400 & 8.0 & 4.0 & 6.0 & 7.0 & 12.0 & \\
\hline & 600 & 10.0 & 6.0 & 7.0 & 9.0 & 6.0 & \\
\hline & 800 & - & 8.0 & 9.0 & 10.0 & 5.0 & \\
\hline \multirow[t]{4}{*}{ Acetone } & 200 & 4.0 & 4.0 & - & - & - & 21.0 \\
\hline & 400 & 5.0 & 5.0 & 5.0 & - & - & \\
\hline & 600 & 6.0 & - & 7.0 & - & 8.0 & \\
\hline & 800 & 3.0 & - & 5.0 & 8.0 & 10.0 & \\
\hline \multirow[t]{4}{*}{ Ethanol } & 200 & 5.0 & & 7.0 & 6.0 & 8.0 & 15.0 \\
\hline & 400 & 8.0 & 10.0 & 13.0 & 14.0 & 17.0 & \\
\hline & 600 & 7.0 & 9.0 & 11.0 & 12.0 & 13.0 & \\
\hline & 800 & 6.0 & 6.0 & 8.0 & 10.0 & 12.0 & \\
\hline \multirow[t]{4}{*}{ Aqueous } & 200 & - & - & - & - & - & 20.5 \\
\hline & 400 & - & 5.0 & - & - & - & \\
\hline & 600 & 5.0 & 4.0 & 4.0 & 6.0 & 6.0 & \\
\hline & 800 & 6.0 & 3.0 & 5.0 & 4.0 & 5.0 & \\
\hline
\end{tabular}

$(-)$ : No response.

the disrupt membrane of Gram-negative bacteria surrounding the cell wall, which prevents the diffusion of hydrophobic compounds across its lipopolysaccharide protection [33,34].

\section{CONCLUSION}

Well-developed green compact callus and maximum (78\%) callus fresh weight was derived from stem explant on MS medium supplemented with $0.7 \mathrm{mg} / \mathrm{l} \mathrm{2}$, 4-D and $0.5 \mathrm{mg} / \mathrm{l} \mathrm{BA}$. C. halicacabum exhibited the potential antibacterial activity against $S$. aureus in both the wild stem and in vitro callus extracts. The FT-IR spectrum of wild stem and callus ethanolic extracts confirm the presence of amino acids, which are widely reported for their antioxidant potential and major functional groups are present in the callus extract. The results confirmed the occurrence of conceivable phytoconstituents, promise effectiveness in the $C$. halicacabum callus extract also.

\section{ACKNOWLEDGMENT}

The authors acknowledge the Department of Botany, Alagappa University, Karaikudi, for providing lab facilities, infrastructure support to conduct the research work.

\section{AUTHORS' CONTRIBUTIONS}

Both authors are equally contributed in performing the experiments and preparation of the manuscript.

\section{CONFLICT OF INTERESTS}

Both authors declare that they have no competing interests.

\section{AUTHOR'S FUNDING}

The authors are also grateful to the RUSA-2.1, for providing financial support.

\section{REFERENCES}

1. Larayetan R, Ololade ZS, Ogunmola OO, Ladokun A. Phytochemical constituents, antioxidant, cytotoxicity, antimicrobial, antitrypanosomally, and antimalarial potentials of the crude extracts of Callistemon citrinus. J Evid Based Complement Altern Med 2019;2019:5410923.
2. Savitha G, Vishnupriya V, Krishnamohan S. Cardiospermum halicacabum Linn. A review. Asian J Pharm Clin Res 2017;10:23-6.

3. Muthumani P, Meera R, Venkatraman S, Ganapathy S, Devi P. Study of phyto chemical, analgesic and antiulcer activity of extracts of aerial parts of Cardiospermum halicacabum Linn. Int J Pharm Sci Res 2010;10:128.

4. Wen CL, Chang CC, Huang SS, Kuo CL, Hsu SL, Deng JS, et al. Antiinflammatory effects of methanol extract of Antrodia cinnamomea mycelia both in vitro and in vivo. J Ethnopharmacol 2011;137:575-84.

5. Murashige T, Skoog F. A revised medium for rapid growth and bio assays with tobacco tissue cultures. Physiol Plant 1962;15:473-97.

6. Banu KS, Cathrine L. General techniques involved in phytochemical analysis. Int J Adv Res Chem Sci 2015;4:25-32.

7. Rao ML, Savithramma N. Antimicrobial activity of silver nanoparticles synthesized by using stem extract of Svensonia hyderobadensis (Walp.) Mold. A rare medicinal plant. Res Biotechnol 2012;3:3.

8. Shah MD, Hossain MA. Total flavonoids content and biochemical screening of the leaves of tropical endemic medicinal plant Merremia borneensis. Arabian J Chem 2014;7:1034-8.

9. Sofowora A. Screening plants for bioactive agents. In: Medicinal Plants and Traditional Medicinal in Africa. $2^{\text {nd }}$ ed. Sunshine House, Ibadan, Nigeria: Spectrum Books Ltd.; 1993. p. 134-56.

10. Ben IO, Woode E, Abotsi WK, Boakye-Gyasi E. Preliminary phytochemical screening and in vitro antioxidant properties of Trichilia monadelpha (Thonn.) JJ De Wilde (Meliaceae). J Med Biomed Sci 2013;2:6-15.

11. Auwal MS, Saka S, Mairiga IA, Sanda KA, Shuaibu A, Ibrahim A. Preliminary phytochemical and elemental analysis of aqueous and fractionated pod extracts of Acacia nilotica (Thorn mimosa). Vet Res Forum 2014;5:2

12. Shaikh JR, Patil MK. Qualitative tests for preliminary phytochemical screening: An overview. Int J Chem Stud 2020;8:603-8.

13. Yadav M, Chatterji S, Gupta SK, Watal G. Preliminary phytochemical screening of six medicinal plants used in traditional medicine. Int $\mathrm{J}$ Pharm Pharm Sci 2014;6:539-42.

14. Ainsworth EA, Gillespie KM. Estimation of total phenolic content and other oxidation substrates in plant tissues using folin-ciocalteu reagent. Nat Protoc 2007;2:875-7.

15. Singh R, Verma PK, Singh G. Total phenolic, flavonoids and tannin contents in different extracts of Artemisia absinthium. J Complement Med Res 2012;1:101-4.

16. Klein SM, Cohen G, Cederbaum AI. Production of formaldehyde during metabolism of dimethyl sulfoxide by hydroxyl radical-generating systems. Biochemistry 1981;20:6006-12.

17. Oyaizu M. Studies on products of browning reaction antioxidative 
activities of products of browning reaction prepared from glucosamine. Jpn J Nutr Diet 1986;44:307-15.

18. Brand-Williams W, Cuvelier ME, Berset CL. Use of a free radical method to evaluate antioxidant activity. LWT Food Sci Technol 1995;28:25-30.

19. Passinho-Soares HC, Meira PR, David JP, Mesquita PR, Vale AE, Rodrigues DM, et al. Volatile organic compounds obtained by in vitro callus cultivation of Plectranthus ornatus Codd. (Lamiaceae). Molecules 2013;18:10320-33.

20. Thaniarasu R, Kumar TS, Rao MV. Mass propagation of Plectranthus bourneae Gamble through indirect organogenesis from leaf and internode explants. Physiol Mol Biol Plants 2016;22:143-51.

21. Erisen S, Yorgancilar M, Atalay E, Babaoglu M. Prolific shoot regeneration of Astragalus cariensis Boiss. Plant Cell Tissue Organ Cult 2010;100:229-33.

22. Bakar DA, Ahmed BA, Taha RM. In vitro callus induction and plant regeneration of Celosia argentea-an important medicinal plant. Braz Arch Biol Technol 2014;57:860-6.

23. Thangavel P, Britto SJ, Prabhu S, Senthil Kumar S. In vitro callus induction and plantlets regeneration from leaf explants of Plectranthus barbatus Andrews-a valuable medicinal plant. Int J Adv Sci Eng 2014;2:51-7.

24. Mangoale RM, Afolayan AJ. Comparative phytochemical constituents and antioxidant activity of wild and cultivated Alepidea amatymbica Eckl and Zeyh. Bio Med Res Int 2020;13:2020.

25. Jeyadevi R, Sivasudha T, Ilavarasi A, Thajuddin N. Chemical constituents and antimicrobial activity of Indian green leafy vegetable Cardiospermum halicacabum. Indian J Microbiol 2013;53:208-13.

26. Visveshwari M, Subbaiyan B, Thangapandian V. Phytochemical analysis, antibacterial activity, FTIR and GC MS analysis of Ceropegia Juncea Roxb. Int J Pharmacogn Phytochem Res 2017;9:914-20.

27. Selvamuthukumaran M, Shi J. Recent advances in extraction of antioxidants from plant by-products processing industries. Food Qual Saf 2017;1:61-81.

28. Muthukumran P, Begumand VH, Kalaiarasan P. Anti-diabetic activity of Dodonaea viscosa (L) leaf extracts. Int J PharmTech Res 2011;3:136-9.

29. Venkanna B, Neelagiri C, Adepally U, Lingam J, Bommareddy K. Phytochemical screening and evaluation of in vitro antioxidant and antimicrobial activities of the indigenous medicinal plant Albizia odoratissima. Pharm Biol 2017;55:1155-61.

30. Generalić Mekinić I, Skroza D, Ljubenkov I, Šimat V, Smole Možina S, Katalinić V. In vitro antioxidant and antibacterial activity of Lamiaceae phenolic extracts: A correlation study. Food Technol Biotechnol 2014;52:119-27.

31. Frezzini MA, Castellani F, De Francesco N, Ristorini M, Canepari S. Application of DPPH assay for assessment of particulate matter reducing properties. Atmosphere 2019;10:816.

32. Jimoh MO, Afolayan AJ, Lewu FB. Antioxidant and phytochemical activities of Amaranthus caudatus L. harvested from different soils at various growth stages. Sci Rep 2019;9:1-14.

33. Thaniarasu R, Senthil Kumar T, Abubacker MN, Rao MV. Preliminary phytochemical screening and evaluation of antibacterial activity of different solvent extracts of Plectranthus bourneae Gamble (Lamiaceae). Asian J Pharm Clin Res 2015;8:79-82.

34. Breijyeh Z, Jubeh B, Karaman R. Resistance of Gram-negative Bacteria to current antibacterial agents and approaches to resolve it. Molecules 2020;25:1340. 